
\title{
(Hylocereus polyhrizus)
}

\author{
Meri Septina ${ }^{1}$ Achyani $^{2}$ Handoko Santoso ${ }^{3}$ \\ 1, Pascasarjana UM Metro SMP Negeri 10 Bandar Lampung, ${ }^{2}$ Pascasarjana UM Metro, ${ }^{3}$ Pascasarjana \\ UM Metro \\ ${ }^{1}$ meri.septinaa@yahoo.com , ${ }^{2}$ acysbd@gmail.com, ${ }^{3}$ handoko.umm@gmail.com,
}

\begin{abstract}
Abstrak: Nata de jamur adalah produk makanan dari fermentasi air rebusan jamur tiram putih. Air rebusan jamur tiram putih memiliki kandungan karbohidrat yang tinggi sekitar 57,6\%-81,8\% berat kering serta kadar air yang tinggi $86,6 \%$. Sehingga dapat dimanfaatkan dalam pembuatan nata de jamur dengan penambahan ekstrak kulit buah naga merah. Tujuan penelitian ini untuk mengetahui organoleptik dan karakteristik kimiawi nata de jamur. Jenis penelitian eksperimendengan desain RAL (Rancangan Acak Lengkap). Analisis data menggunakan One Way Anova. Hasil penelitian pada sebelumnya nata de leri diterima oleh masyarakat dan dapat dijadikan referensi bahan praktikum belajar biologi jenjang SMA kelas 12 .
\end{abstract}

Kata kunci: Air rebusan jamur tiram putih, nata de jamur, ekstrak kulit buah naga merah

\begin{abstract}
Abstrack: Nata de mushroom is a food product from the fermentation of boiled water of white oyster mushrooms. White oyster mushroom boiled water has a high carbohydrate content of about 57.6\%$81.8 \%$ dry weight and a high water content of $86.6 \%$. So that it can be used in the manufacture of nata de mushrooms with the addition of red dragon fruit peel extract. The purpose of this study was to determine the organoleptic and chemical characteristics of nata de mushroom. This type of research is experimental with RAL design (Completely Randomized Design). Data analysis using One Way Anova. The results of previous research on nata de leri are accepted by the community and can be used as a reference material for studying biology at the 12th grade high school level.
\end{abstract}

Key word: White oyster mushroom boiled water, nata de mushroom, red dragon fruit peel extract

\section{How To Cite:}

Septina, Meri, Achyani, Handoko Santoso. 2022. Pemanfaatan Air Rebusan Jamur Tiram Putih dalam Pembuatan Nata De Jamur dengan Penambahan Ekstrak Kulit Buah Naga Merah (Hylocereus polyhrizus). BIOLOVA 3(1). 52-56. 
Jamur tiram merupakan salah satu komoditi eskspor Indonesia yang mempunyai prospek sangat baik untuk dikembangkan. Jamur tiram setiap 100 gramnya mengandung protein $19-35 \%$ dengan 9 macam asam amino, lemak $1,7-2,2 \%$ terdiri dari $72 \%$ asam lemak tak jenuh. (Egra, 2018). Selain itu karbohidrat jamur terdiri dari tiamin, riboflavin, dan niasin merupakan vitamin B utama dalam jamur tiram, selain vitamin $\mathrm{D}$ dan $\mathrm{C}$ mineralnya terdiri dari $\mathrm{K}, \mathrm{P}, \mathrm{Mg}, \mathrm{Ca}, \mathrm{Na}, \mathrm{Fe}, \mathrm{Zn}$, $\mathrm{Mn}$, Co dan $\mathrm{Pb}$. Mikroelemen yang bersifat logam sangat rendah sehingga aman dikonsumsi setiap hari (Sumarni, 2006). Kandungan yang ada di dalam jamur tiram dapat bermanfaat diantaranya yaitu menurunkan kadar kolesterol darah, meningkatkan imun tubuh, mencegah hypertensi, dan mencegah tumor dan kanker (Hedritomo, 2008). Karena sifat jamur tiram yang adaptif terhadap perubahan lingkungan dan memiliki produktifitas tinggi membuat petani Indonesia membudidayakan tanaman ini. Kandungan air yang tinggi pada jamur tiram ini mencapai $86,6 \%$ sehingga membuat mudah sekali rusak setelah dipanen. (Djarijah, 2001). Kandungan air yang terdapat didalam jamur tiram cukup tinggi sehingga saat diolah atau direbus air yang dihasilkan juga sangat banyak selain itu air rebusan jamur tiram tersebut hanya dibuang sia-sia begitu saja. Terutama bagi pengusaha atau pedagang makanan olahan dari jamur tiram ini saat pengolahan air rebusannya ktentu saja dibuang begitu saja tidak dimanfaatkan lagi. Air rebusan jamur tiram ini juga mengandung zat gizi yang terbawa saat perebusan. Jamur tiram putih memiliki kandungan karbohidrat yang tinggi sekitar 57,6\%-81,8\% berat kering. Karbohidrat tak tercernakan merupakan saah satu karbohidrat terbanyak dalam jamur yang tahan terhadap enzim manusia dan dapat dipertimbangkan sebagai sumber nutrisi. Diantaranya, oligosakarida seperti trehalose dan polisakarida seperti kitin, $\beta$-glukan dan manan. Kandungan $\beta$-glukan pada polisakarida sangat tinggi yang memiliki efek biofarmakologi yang bermanfaat bagi kesehatan sebagai bahan imunologi. (Jayakumar, 1996)

Karena bahan dasar nata adalah air sehingga air rebusan jamur tiram ini masih bisa digunakan untuk bahan dasar pembuatan nata de jamur yang biasanya jamur diolah menjadi lauk makan sehari-hari serta pengolahan jamur di home industry air rebusan nya hanya terbuang ini dapat dimanfaatkan untuk pembuatan nata de jamur. Sebagaimana pada penelitian terdahulu, bahwa menggunakan air cucian beras organik dengan penambahan ekstrak kulit buah naga merah menghasilkan nata de leri yang dapat dikonsumsi. (Septina, 2019). Selain itu pemanfaatan kulit buah naga merah yang mengandung antosianin dan pigmen warna merah alami digunakan untuk memberikan warna merah pada nata yang dihasilkan. Kulit buah naga merah memiliki kandungan pigmen pewarna merh alami yang disebut dengan Antioksidan (Rahayu, 2014). Untuk itu saya ingin melanjutkan penelitian nata ini menggunakan air rebusan jamur tiram putih yang biasanya air rebusan ini tidak digunakan lagi dan hanya terbuang begitu saja sehingga memiliki nilai manfaat yang dapat digunakan dalam produksi nata de jamur sekaligus menjadi alternatif dalam membuat nata dengan inovasi yang baru.

\section{METODE}

Pelitian ini merupakan penelitian eksperimen dengan perlakuan berupa penggunaan air rebusan jamur $75 \mathrm{~mL}$, $50 \mathrm{~mL}$, dan $25 \mathrm{~mL}$, dan penambahan ekstrak kulit buah naga, serta 
perlakuan kontrol. Teknik pengumpulan data dengan melakukan pengamatan terhadap kadar air, serat, dan uji organoleptik. Analisis data menggunakan uji Anava One Way.

\section{HASIL}

Berdasarkan hasil wawancara serta latar belakang serta referensi-referensi yang mendukung bahwa masih kurangnya pemanfaatan dalam memanfaatkan air rebusan jamur tiram putih serta kulit buah naga merah yang masih banyak terbuang sia-sia untuk itu hal yang pertama yang harus dilakukan mecari sebanyak-banyaknya air rebusan jamur tiram putih dan kulit buah naga merah yang masih layak digunakan bukan yang sudah busuk atau sudah terkontaminasi. Selanjutnya memilih stater Acetobacter xylinum yang berkualitas serta mensterilkan alat yang digunakan sebelum dipakai untuk pembuatan nata de jamur. Selain itu pada nata de leri penelitian sebelumnya nata yang dihasilkan berkadar air tinggi serta kadar serat tinggi. Tidak hanya itu hasil organoleptik juga banyak para panelis menyukai nata de jamur hanya pada aroma nata yang kurang disukai karna berbau asam.

Tabel 1. Kualitas Nata de Leri.

\begin{tabular}{|l|l|l|l|l|l|}
\hline \multicolumn{2}{|l|}{ Organoleptik Nata de jamur } & \multicolumn{2}{l|}{ Kualitas Gizi } \\
\hline rasa & warna & aroma & tekstur & $\begin{array}{l}\text { Kadar } \\
\text { serat }\end{array}$ & $\begin{array}{l}\text { Kadar } \\
\text { air }\end{array}$ \\
\hline disukai & disukai & $\begin{array}{l}\text { Asam } \\
\text { tak } \\
\text { disukai }\end{array}$ & disukai & Tinggi & Tinggi \\
\hline
\end{tabular}

\section{PEMBAHASAN}

Pemanfaatan air rebusan jamur tiram putih dapat diolah menjadi nata de jamur. Budidaya Jamur tiram di Indonesia tergolong tinggi peminatnya karena sifatnya yang mudah untuk tumbuh dan berkembang. Selain itu, jamur tiram juga memiliki manfaat yang baik untuk kesehatan manusia.
Berdasarkan analisis mengenai kandungan yang terdapat di dalam jamur tiram putih serta air rebusannya. Kandungan air yang tinggi mencapai $86,6 \%$ membuat jamur tiram putih mudah rusak setelah dipanen. (Sulistyowati, 2004). Jamur tiram putih juga mengandung sejumlah vitamin penting terutama kelompok vitamin B. Kandungan vitamin B1 (tiamin), B2 (riboflavin), niasin dan provitamin D2 (ergosterol)-nya cukup tinggi. Jamur merupakan sumber mineral yang baik, kandungan mineral utama yang tertinggi adalah kalium $(\mathrm{K})$, kemudian fosfor $(\mathrm{P})$, natrium $(\mathrm{Na})$, kalsium $(\mathrm{Ca})$ dan magnesium (Mg) (Gunawan, 2000). Selain itu, jamur juga merupakan sumber mineral minor yang baik karena mengandung seng, besi, mangan, molibdenum, kadmium, dan tembaga. Konsentrasi $\mathrm{K}, \mathrm{P}, \mathrm{Na}, \mathrm{Ca}$ dan $\mathrm{Mg}$ mencapai 56$70 \%$ dari total abu, dengan kandungan kalium sangat tinggi mencapai $45 \%$. Jamur tiram putih memiliki kandungan karbohidrat yang tinggi sekitar $57,6 \%-81,8 \%$ berat kering (Widiyastuti,2001).

Karbohidrat yang terkandung di dalamnya antara lain, oligosakarida seperti trehalose dan polisakarida seperti kitin, $\beta$-glukan dan manan. Kandungan $\beta$-glukan pada polisakarida sangat tinggi yang memiliki efek biofarmakologi yang bermanfaat bagi kesehatan sebagai bahan imunologi (Saskiawan dkk, 2015).

Nata sendiri merupakan hasil olahan makanan yang memanfaatkan makhluk hidup berupa bakteri Acetobacter xylinum melalui proses fermentasi. Proses fermentasi Acetobacter xylinum menghasilkan asam asetat dan lapisan putih mengambang di permukaan medium yang mengandung gula yang selanjutnya disebut sebagai Nata (Sutanto, 2012). Syarat yang 
dibutuhkan dalam pertumbuhan Acetobacter xylinum dalam memproduksi nata adalah ketersediaannya nutrisi seperti karbohidrat, protein, dan mineral lainnya. Dalam air kelapa mengandung air sebanyak 91, 23\%, karbohidrat $7,2 \%$, protein $0,29 \%$, lemak $0,15 \%$ serta serat abu $1,06 \%$ juga nutrisi-nutrisi lain berupa sukrosa, fruktose, serta vitamin B kompleks.

Kulit buah naga mengandung zat warna alami antosianin yang cukup tinggi (Kristianto, 2009). Antosianin adalah zat yang memberikan warna merah alami yang berpotensi menjadi pewarna untuk bahan pangan dan dapat dijadikan alternatif sebagai pengganti pewarna sintesis yang lebih aman dikonsumsi bagi kesehatan. Air, karbohidrat, asam, protein, serat, kalsium, fosfor, magnesium, vitamin C juga terkandung didalam kulit buah naga merah (Murtiono, 2015). Kandungan yang terdapat baik pada air rebusan jamur dan kulit buah naga menyediakan tempat hidup yang sesuai dengan pertumbuhan bakteri Acetobacter xylinum sehingga membentuk nata, dengan hasil disukai oleh panelis. Berdasarkan analisis dalam pembuatan nata sebelumnya penggunaan stater Acetobacter xylinum merupakan faktor yang sangat penting dalam mendukung keberhasilan pembuatan nata. Sehingga dalam pembuatan nata de jamur ini hal yaang perlu diperhatikan dalam memilih air rebusan jamur tiram putih dan pemilihan kulit buah naga merah. Perlakuan yang baik terjadi pada perlakuan pertama dengan air jamur $75 \mathrm{ml}$ ditambahkan dengan $75 \mathrm{ml}$ ekstrak kulit buah naga merah menghasilkan nata yang berukuran tebal, bening, dan tidak tipis.

\section{KESIMPULAN}

Berdasarkan data penelitian dan pembahasan bahwa nata de jamur diharapkan dapat diterima juga dan disukai oleh masyarakat seperti halnya nata de leri. Berdasarkan pada penelitian nata de leri perlakuan yang menghasilkan nata yang baik yaitu pada air cucian beras putih dengan ukuran $75 \mathrm{ml}$ ditambahkan dengan 75 ml ekstrak kulit buah naga merah. Selain itu kandungan serat dan kandungan air nata de leri yang terkandung juga tinggi Dan diharapakan dapat penelitian ini dapat menjadi referensi dan sumbangsih dalam pendidikan yaitu bahan praktikum di jenjang SMA.

\section{SARAN}

Dalam penulisan serta penelitian masih banyak kekurangan untuk itu penulis membutuhkan saran dari pembaca agar lebih baik lagi dan lebih teliti lagi. Semoga kedepannya penelitian ini dapat diterima oleh masyarakat serta berguna bagi pendidikan.

\section{DAFTAR RUJUKAN}

Djarijah, N. M. 2001. Budidaya Jamur Tiram: Pembibitan,

Pemeliharaan dan

Pengendalian Hama Penyakit. Kanisius. Yogyakarta.

Egra, S., Kusuma, IW., Arung, ET,. 2018.Kandungan Antioksidan Pada Jamur Tiram Putih (Pleurotus ostreatus). Jurnal Hut Trop, 2 (2)

Gunawan, A. W. 2000. Usaha Pembibitan Jamur. Penebar Swadaya. Jakarta.

Hedritomo, H. I., D. Tjokrokusumo, dan Djajanegara. 2008. Pengaruh Mutasi Radiasi Sinar Gamma (Co60) terhadap Produksi Jamur Tiram Putih 
(Pleurotus ostreatus). Jurnal Biotika

Jayakumar, T., Ramesh, E., dan Geraldine, P. 2006. Antioxidant activity of the oyster mushroom, Pleurotus ostreatus, on CCl4 induced liver injury in rats. Food and Chemical Toxicology, 44(12)

Kristanto, D. 2009 Buah Naga Pembudidayaan di Pot dan Di Kebun Jakarta: Penebar Swadaya

Lisa, M., Luthfi, M, Susilo., B,. 2015. Pengaruh Suhu dan Lama Pengeringan Terhadap Mutu Tepung Jamur Tiram Putih (Pleurotus ostreatus). Jurnal Keteknikan Pertanian Tropis dan Biosistem

Murtiono, A. 2015 "Pemanfaatan Kulit Buah Naga (Hylocereus polyhrizus) Sebagai Pewarna Alami Dengan Metode Ekstraksi”. Laporan Akhir Pendidikan Diploma III Jurusan Teknik Kimia Politeknik Negeri Sriwijaya, Palembang

Rahayu, S. 2014. Budidaya Buah Naga Cepat Panen. Malang: Infra Hijau

Saskiawan, I., dan Hasanah, N. 2015. Aktivitas antimikroba dan antioksidan senyawa polisakarida jamurtiram putih (Pleurotus ostreatus). Pros Sem Nas Masy Biodiv Indon, 1(5)

Septina, M., Pawhestri, SW., Widiani, N., Budi, R. 2019. The Utilization of Rice Wastewater Combined With Red Dragon Fruit (Hylocereus polyrhizus) as Basic Ingredients of Nata De Leri. Jurnal Ilmiah Biologi
Eksperimen dan

Keanekaragaman Hayati, 6

(1)

Sulistyowati, R. 2004. Pengaruh Suhu dan Lama Pengeringan dengan menggunalan Cabinet Dryer terhadap Kadar Air, Protein dan Lemak pada Jamur Tiram Putih (Pleurotus ostreatus). Fakultas Keguruan dan Ilmu Pendidikan Universitas Muhammadiyah. Malang.

Sumarni, 2006. Botani dan Tinjauan Gizi Jamur Tiram Putih. INNOFAR: Jurnal Inovasi Pertanian. Vol. 4, No. 2

Sutanto, A. (2012). Pineapple liquid waste as nata de pina raw material. Makara Journal of Technology, 16(1), 63-6.

Widyastuti. 2001. Budidaya Jamur Kompos:Jamur Merang, Jamur Kancing. Penebar Swadaya : Jakarta. 
